\title{
Inhibition of protein synthesis but not $\beta$-adrenergic receptors blocks reconsolidation of a cocaine-associated cue memory
}

\author{
Amber B. Dunbar ${ }^{1,2}$ and Jane R. Taylor ${ }^{1,2,3}$ \\ ${ }^{1}$ Department of Psychiatry, Division of Molecular Psychiatry; ${ }^{2}$ Department of Psychology; ${ }^{3}$ Interdepartmental Neuroscience Program, \\ Yale University, New Haven, Connecticut 06520, USA
}

\begin{abstract}
Previously consolidated memories have the potential to enter a state of lability upon memory recall, during which time the memory can be altered before undergoing an additional consolidation-like process and being stored again as a longterm memory. Blocking reconsolidation of aberrant memories has been proposed as a potential treatment for psychiatric disorders including addiction. Here we investigated of the effect of systemically administering the protein synthesis inhibitor cycloheximide or the $\beta$-adrenergic antagonist propranolol on reconsolidation. Rats were trained to self-administer cocaine, during which each lever press resulted in the presentation of a cue paired with an intravenous infusion of cocaine. After undergoing lever press extinction to reduce operant responding, the cue memory was reactivated and rats were administered systemic injections of propranolol, cycloheximide, or vehicle. Post-reactivation cycloheximide, but not propranolol, resulted in a reactivation-dependent decrease in cue-induced reinstatement, indicative of reconsolidation blockade by protein synthesis inhibition. The present data indicate that systemically targeting protein synthesis as opposed to the $\beta$-adrenergic system may more effectively attenuate the reconsolidation of a drug-related memory and decrease drug-seeking behavior.
\end{abstract}

Previously consolidated memories have the potential to enter a state of lability upon memory recall, during which time the memory can be altered before undergoing an additional consolidation-like process and being stored again as a long-term memory (e.g., Nader et al. 2000b; Tronson and Taylor 2007). This process, known as memory reconsolidation, is thought to occur as a means of updating memories when new information pertaining to those memories is encountered (Rodriguez-Ortiz and Bermudez-Rattoni 2007; Jones et al. 2012). Manipulations of memory reconsolidation not only can update learned memories with new information but also can strengthen or weaken preexisting memories (Tronson et al. 2006). In fact, interfering with memory reconsolidation has been shown to block memory in a variety of learning paradigms in rodents, including spatial learning (Przybyslawski et al. 1999; Flint et al. 2007), object recognition (Winters et al. 2009; Balderas et al. 2015), and fear conditioning (Nader et al. 2000a; Tronson et al. 2006). A number of amnestic agents have been identified that effectively block reconsolidation in such paradigms, including NMDAR antagonists (Lee et al. 2006; Winters et al. 2009), $\beta$-adrenergic receptor antagonists (Przybyslawski et al. 1999; Debiec and LeDoux 2004), and protein synthesis inhibitors (Nader et al. 2000a; Morris et al. 2006).

Recently, manipulations of memory reconsolidation have been investigated in the context of appetitive memories, specifically as potential treatments for addiction and relapse-like behavior (e.g., Taylor et al. 2009; Sorg 2012; Torregrossa and Taylor 2013, 2016; Taylor and Torregrossa 2015). More traditional methods of reducing relapse-like behavior in rodents utilize extinction paradigms, in which a cue previously paired with the drug is presented repeatedly in the absence of the drug until the cue no lon-

\section{Corresponding author: jane.taylor@yale.edu}

Article is online at http://www.learnmem.org/cgi/doi/10.1101//m.042838. 116. ger elicits drug-seeking behavior. Because the extinction paradigm induces the learning of a new, inhibitory memory, the original memory still exists within the brain and is subject to renewal and spontaneous recovery, which can lead to relapse-like behavior (Bouton 2004). Reconsolidation blockade, conversely, is thought to directly alter and/or update the original memory, leading to a long-lasting, context-independent change and, thus, to provide potentially superior relapse prevention (Lee et al. 2005; Milekic et al. 2006; Sanchez et al. 2010). Interfering with memory reconsolidation in rodents has been shown to block memories related to a number of drugs, including morphine (Valjent et al. 2006; Taubenfeld et al. 2010), ethanol (Wouda et al. 2010; Schramm et al. 2015), nicotine (Fang et al. 2011; Tedesco et al. 2014), methamphetamine (Zhao et al. 2011b; Yu et al. 2013), amphetamine (Sadler et al. 2007; Contreras et al. 2012), heroin (Hellemans et al. 2006; Jian et al. 2014), and cocaine (Milton et al. 2008; Sanchez et al. 2010). Notably, manipulations of memory reconsolidation have also been reported to decrease the strength of drug-related memories in humans (Zhao et al. 2011a; Saladin et al. 2013).

Most investigations of reconsolidation of drug-related memories have utilized a conditioned place preference (CPP) model in rodents, in which the drugs are administered by the experimenter (Prus et al. 2009). Amnestic agents shown to block reconsolidation in neutral and aversive paradigms can also block appetitive memories in the CPP paradigm. For example, both morphineand cocaine-CPP can be systemically blocked by administration of the $\beta$-adrenergic antagonist propranolol (Robinson and

(C) 2016 Dunbar and Taylor This article is distributed exclusively by Cold Spring Harbor Laboratory Press for the first 12 months after the full-issue publication date (see http://learnmem.cshlp.org/site/misc/terms.xhtml). After 12 months, it is available under a Creative Commons License (AttributionNonCommercial 4.0 International), as described at http://creativecommons. org/licenses/by-nc/4.0/. 
Franklin 2010; Otis et al. 2013) as well as by the protein synthesis inhibitors cycloheximide and anisomycin (Fan et al. 2010; Milekic et al. 2006).

Still unknown is whether systemic injections of propranolol or cycloheximide will block reconsolidation of a cocaine-cue memory that drives reinstatement in rats that have learned to selfadminister cocaine. Drug self-administration paradigms may be more ethologically valid models when compared with CPP, since animals are able to control the timing and amount of voluntary drug-intake. Understanding whether drugs that block CPP reconsolidation also block self-administration memories is essential for the translational potential of reconsolidation-based addiction treatments. Of additional importance to the translational benefit of reconsolidation-based treatments is whether the amnestic agent can be administered systemically, as opposed to the majority of rodent studies that administer such agents intracranially in order to examine brain-specific mechanisms. Anisomycin, for example, has been shown to block reconsolidation and cue-induced reinstatement in a rodent model of cocaine self-administration when administered into the medial PFC (Sorg et al. 2015), but the systemic potential of protein synthesis inhibitors to block reconsolidation of self-administration memories has not been reported. Additionally, systemic propranolol has been demonstrated to block reconsolidation of the conditioned-reinforcement value of a cue previously paired with cocaine (Milton et al. 2008), but the ability of post-retrieval propranolol to block cue-induced reinstatement has yet to be examined. As cue-induced reinstatement models relapse-like behavior, assessing the effects of propranolol and cycloheximide on reinstatement will provide insight into the translational potential of such compounds in treating addiction through interfering with reconsolidation.

The present study thus investigates whether systemic administration of cycloheximide or propranolol can block reconsolidation of a cocaine-cue memory and reduce cue-induced reinstatement to cocaine-seeking in rats that have been trained to selfadminister intravenous cocaine. Rats underwent self-administration training during which each active lever press resulted in the contingent presentation of a cue paired with a cocaine infusion. Following self-administration, rats underwent lever extinction in order to reduce responding on the active lever so that reinstatement could later be measured. The cue memory was then reactivated by presentations of the cue in the absence of cocaine. Immediately following memory retrieval, animals received systemic injections of the amnestic agent cycloheximide or propranolol and were tested 1 to $3 \mathrm{~d}$ later on cue-induced reinstatement. It was hypothesized that rats that received propranolol or cycloheximide would demonstrate decreased responding on reinstatement day, indicative of reduced drug-seeking behavior caused by reconsolidation blockade. In support of the hypothesis, cycloheximide effectively decreased reinstatement in a dose- and reactivation-dependent manner, indicative of reconsolidation blockade, whereas no effect of propranolol on reinstatement or reconsolidation was found.

\section{Results}

\section{Effect of low dose $(1.0 \mathrm{mg} / \mathrm{kg})$ of cycloheximide on reconsolidation}

We first tested whether a low dose of the protein synthesis inhibitor cycloheximide could block reconsolidation. Rats were trained in cocaine self-administration in which each lever press resulted in one infusion of cocaine $(0.5 \mathrm{mg} / \mathrm{kg})$ paired with the conditioned stimulus (CS). Lever pressing was subsequently extinguished to reduce responding. Memory reactivation occurred $24 \mathrm{~h}$ after the last day of lever extinction and consisted of three non-contingent CS presentations in the absence of any cocaine or levers. Rats received injections of vehicle or cycloheximide ( $1.0 \mathrm{mg} / \mathrm{kg}$, s.c.) immediately following CS memory reactivation, and cue-induced reinstatement was tested $72 \mathrm{~h}$ later (Fig. 1A).

Across the $10 \mathrm{~d}$ of cocaine self-administration training, there were no differences in number of cocaine infusions (Fig. 1B), active lever presses, or inactive lever presses between rats that would be injected following memory reactivation with cycloheximide $(N=8)$ or vehicle $(N=9 ; P$ values $>0.05)$. Likewise, no differences were found between groups across the $8 \mathrm{~d}$ of lever extinction on the number of active (Fig. 1C) or inactive lever presses $(P$ values $>0.05)$. A main effect of session (last day of extinction versus reinstatement) was obtained on active lever presses $\left(F_{(1,15)}=18.16, P=0.001, \eta_{\mathrm{p}}{ }^{2}=0.55\right)$, such that rats pressed the active lever more on reinstatement when compared with the last day of extinction, but there was not a significant drug by session interaction on active lever presses (Fig. 1D; $\left.F_{(1,15)}=1.26, P=0.28, \eta_{\mathrm{p}}{ }^{2}=0.08\right)$. No main effects or interaction between session and drug on inactive lever presses was obtained $(P$ values $>0.05)$. These data indicate that a $1.0 \mathrm{mg} / \mathrm{kg}$ dose of cycloheximide is insufficient to reduce reconsolidation or cue-induced reinstatement.
A
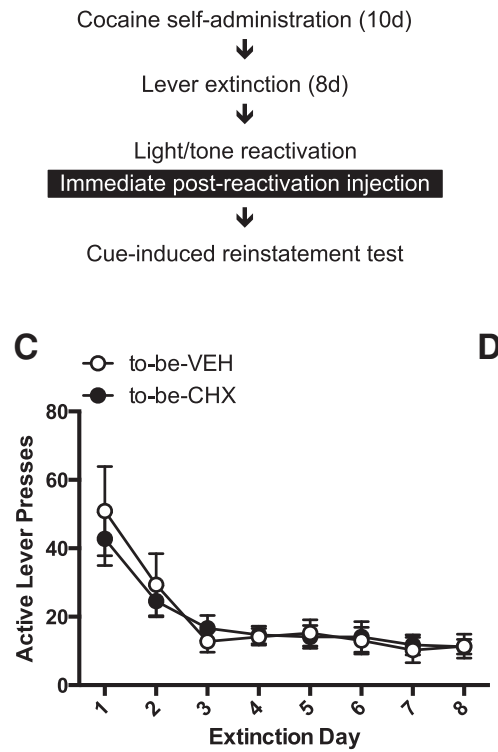

D
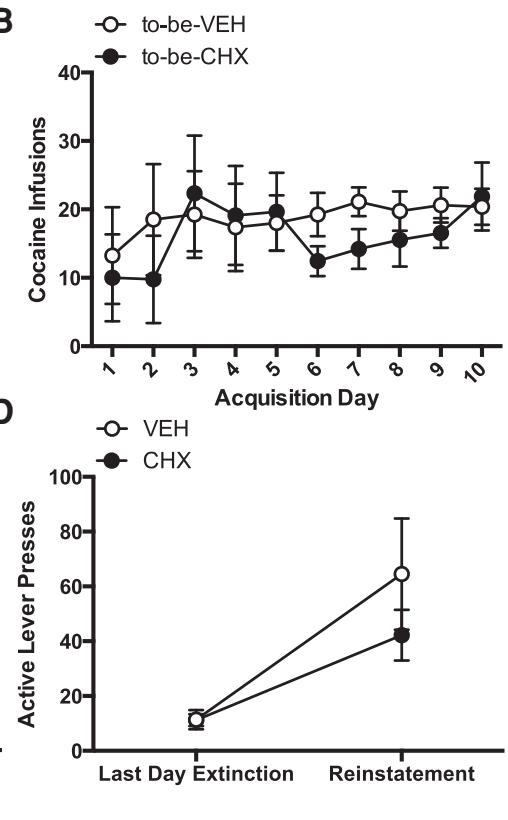

Figure 1. A low dose of cycloheximide $(1.0 \mathrm{mg} / \mathrm{kg})$ does not affect reconsolidation or cue-induced reinstatement. (A) Schematic representation of the experimental procedures. (B) Total number of cocaine infusions received across each day of self-administration. (C) Total number of active lever presses during lever extinction. $(D)$ Active lever presses on the last day of extinction and on the cue-induced reinstatement test. $(\mathrm{Ns}=8(\mathrm{VEH}), 9(\mathrm{CHX}))$. 


\section{Effect of high dose $(2.2 \mathrm{mg} / \mathrm{kg})$ of cycloheximide on reconsolidation}

In order to examine whether a higher dose of cycloheximide could block reconsolidation, rats previously trained in cocaine self-administration received injections of vehicle or cycloheximide $(2.2 \mathrm{mg} / \mathrm{kg}$, s.c.) immediately following CS memory reactivation and were tested on cue-induced reinstatement $72 \mathrm{~h}$ later (Fig. 2A). Across the $10 \mathrm{~d}$ of cocaine self-administration acquisition, no differences were found between rats that would be injected following memory reactivation with vehicle $(N=9)$ or cycloheximide $(N=9)$ on number of cocaine infusions (Fig. $2 \mathrm{~B})$, active lever presses, or inactive lever presses ( $P$ values $>0.05$ ). Likewise, the number of active lever presses (Fig. 2C) and inactive lever presses across the $8 \mathrm{~d}$ of extinction did not differ between groups $(P$ values $>0.05)$.

A significant main effect was found of session (last day of extinction versus reinstatement) on inactive lever presses $\left(F_{(1,16)}=\right.$ $\left.6.71, P=0.020, \eta_{\mathrm{p}}^{2}=0.30\right)$, such that inactive lever presses increased on reinstatement $(M=4.89 \pm 0.94)$ versus last day of extinction $(M=2.33 \pm 0.58)$. There was also a significant main effect of drug on inactive lever presses during the last day of extinction and reinstatement $\left(F_{(1,16)}=5.34, P=0.035, \eta_{\mathrm{p}}^{2}=0.25\right)$, such that vehicle-injected rats $(M=5.00 \pm 0.85)$ pressed the inactive lever more than cycloheximide-injected rats $(M=2.22 \pm$ 0.85). Importantly, however, there was no significant interaction between session and drug on inactive lever presses $(P<0.05)$, indicating that the main effects on inactive lever presses were not due to administration of the drug but due to preexisting differences between groups.

A significant main effect of session on active lever presses was also obtained $\left(F_{(1,16)}=40.40, P<0.01, \eta_{\mathrm{p}}^{2}=0.72\right)$, such that rats pressed the active lever more on reinstatement when compared with the last day of extinction (Fig. 2D). Additionally, a significant

A

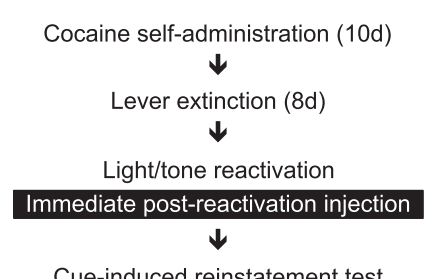

Cue-induced reinstatement test
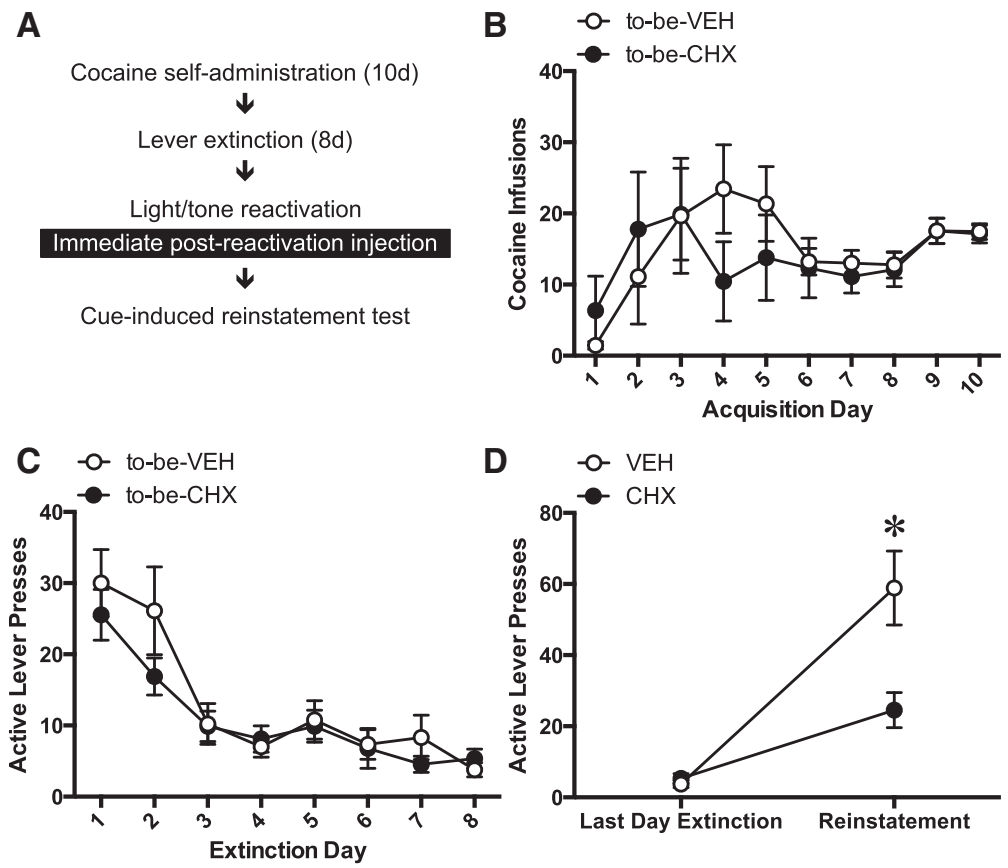

D $-\mathrm{VEH}$

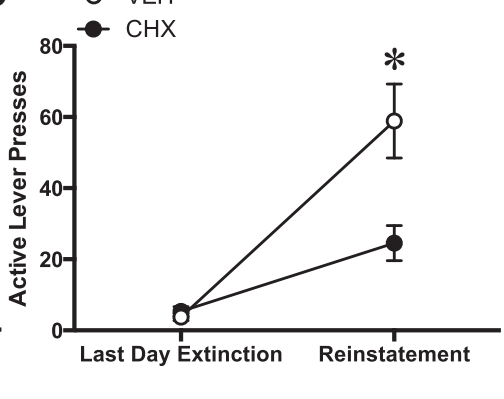

Figure 2. Cycloheximide $(2.2 \mathrm{mg} / \mathrm{kg})$ blocks reconsolidation and reduces cue-induced reinstatement. (A) Schematic representation of the experimental procedures. $(B)$ Total number of cocaine infusions received across each day of self-administration. (C) Total number of active lever presses during lever extinction. $(D)$ Active lever presses on the last day of extinction and on the cue-induced reinstatement test. ${ }^{*}$, Statistically significant $(P<0.05)$. (Ns $\left.=9(\mathrm{VEH}), 9(\mathrm{CHX})\right)$. main effect of drug on active lever presses during the last day of extinction and reinstatement was found $\left(F_{(1,16)}=8.01, P=\right.$ $\left.0.012, \eta_{\mathrm{p}}^{2}=0.33\right)$, such that rats receiving cycloheximide pressed the active lever less than rats receiving vehicle; however, this main effect was qualified by a significant interaction between session and drug (Fig. 2D; $F_{(1,16)}=9.42, P<0.01, \eta_{\mathrm{p}}{ }^{2}=0.37$ ). Whereas both groups responded equivalently on the active lever on the last day of extinction $(P>0.05)$, on the cue-reinstatement test rats that received post-reactivation cycloheximide had significantly fewer active lever presses than vehicle-injected rats $\left(F_{(1,16)}=8.89, P<0.01, \eta_{\mathrm{p}}^{2}=0.36\right)$. These data indicate that postreactivation cycloheximide $(2.2 \mathrm{mg} / \mathrm{kg})$ selectively decreases reinstatement to cocaine seeking on the lever previously associated with cocaine through interfering with reconsolidation.

\section{Effect of high dose $(2.2 \mathrm{mg} / \mathrm{kg})$ of cycloheximide in the absence of reactivation}

To investigate whether the effect of cycloheximide on reinstatement depends upon reactivation and to rule out nonreconsolidation-based mechanisms of cycloheximide's effect, rats received cycloheximide or vehicle treatment following exposure to the novel context without the presence of cocaine-related CSs, and rats were tested $72 \mathrm{~h}$ later on cue-induced reinstatement (Fig. 3A). No differences were seen across the $10 \mathrm{~d}$ of cocaine selfadministration acquisition between nonreactivated rats that would later be injected with vehicle $(N=8)$ or cycloheximide $(N=8)$ on number of cocaine infusions (Fig. 3B), active lever presses, or inactive lever presses $(P$ values $>0.05)$. Similarly, no between-groups differences in active lever presses (Fig. 3C) or inactive lever presses were found across the $8 \mathrm{~d}$ of lever extinction $(P$ values $>0.05)$.

A significant main effect of session (last day of extinction versus reinstatement) on active lever presses was found $\left(F_{(1,14)}=\right.$ $\left.60.05, P<0.01, \eta_{\mathrm{p}}^{2}=0.81\right)$, such that responding was higher on reinstatement when compared with the last day of extinction (Fig. 3D). However, no interaction was seen on active lever presses during the last day of extinction and the cue-induced reinstatement test for vehicle- and cycloheximide-injected rats (Fig. 3D; $F_{(1,14)}=2.82, \quad P=0.12$, $\left.\eta_{\mathrm{p}}^{2}=0.17\right)$. Furthermore, no significant main effect or interaction was found for inactive lever presses on reinstatement and the last day of extinction $(P$ values $>0.05)$. These data indicate that cycloheximide's effect of decreasing cue-reinstatement requires memory reactivation, a critical component for reconsolidation blockade.

\section{Effect of propranolol $(10 \mathrm{mg} / \mathrm{kg})$ on reconsolidation}

In order to test whether the $\beta$-adrenergic receptor antagonist propranolol blocks memory reconsolidation, propranolol $(10 \mathrm{mg} / \mathrm{kg})$ or vehicle was administered immediately following CS memory reactivation, and cue-induced reinstatement was tested $24 \mathrm{~h}$ later (Fig. 4A). Across the $8 \mathrm{~d}$ of cocaine self-administration, no differences were found between rats that would be injected following 
A
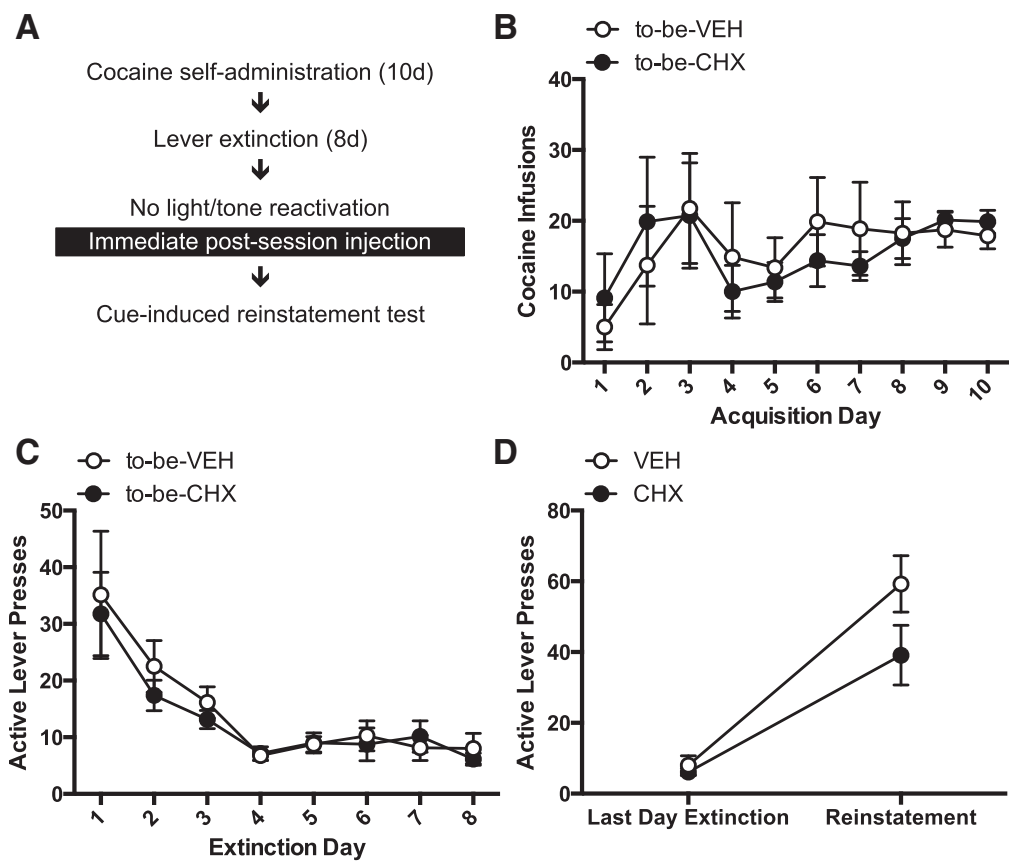

Figure 3. The effect of cycloheximide $(2.2 \mathrm{mg} / \mathrm{kg})$ is dependent upon cue reactivation. $(A)$ Schematic representation of the experimental procedures for rats that did not receive light/tone reactivation. (B) Total number of cocaine infusions received across each day of self-administration. (C) Total number of active lever presses during lever extinction. $(D)$ Active lever presses on the last day of extinction and on the cue-induced reinstatement test. $(\mathrm{Ns}=8(\mathrm{VEH}), 8(\mathrm{CHX}))$.

memory reactivation with vehicle $(N=9)$ or propranolol $(N=9)$ on number of cocaine infusions (Fig. 4B), active lever presses, or inactive lever presses $(P$ values $>0.05$ ). Likewise, no differences were found between groups across the $8 \mathrm{~d}$ of lever press extinction for active lever presses (Fig. $4 C)$ or inactive lever presses ( $P$ values $>0.05$ ). A significant main effect of session (last day of extinction versus reinstatement) on active lever presses was found, such that rats pressed the active lever significantly more on reinstatement compared with the last day of extinction (Fig. 4D; $F_{(1,16)}=57.91, P<$ $\left.0.01, \eta_{\mathrm{p}}{ }^{2}=0.78\right)$. A significant main effect of session (last day of extinction versus reinstatement) on inactive lever presses was also found, such that rats pressed the inactive lever significantly more on reinstatement $(M=6.22 \pm$ 1.03) when compared with the last day of extinction $\left(M=3.28 \pm 0.68 ; F_{(1,16)}=\right.$ 17.78, $\left.P<0.01, \eta_{\mathrm{p}}^{2}=0.53\right)$. However, no interaction between session and drug on active lever presses (Fig. 4D; $\left.F_{(1,16)}=0.038, P=0.85, \eta_{\mathrm{p}}^{2}<0.01\right)$ or inactive lever presses $\left(F_{(1,16)}=0.513\right.$, $\left.P=0.48, \quad \eta_{\mathrm{p}}^{2}=0.03\right) \quad$ was obtained. These data indicate that propranolol does not affect reconsolidation of a cocaine-cue memory.

In light of the null findings, no control experiments were performed using propranolol. Additional doses of proCue-induced reinstatement test

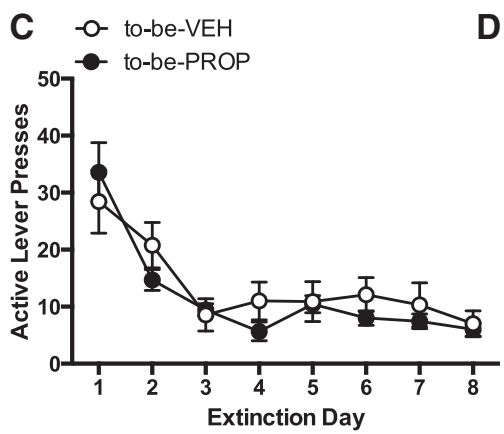
$(\mathrm{Ns}=9$ (VEH), 9 (CHX)).
A

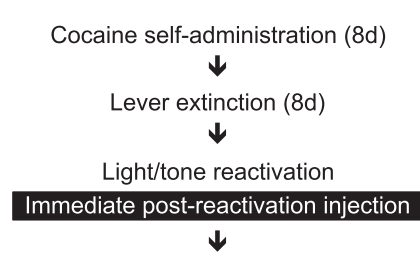

Cue-induced reinstatement test nal hypothesis, post-reactivation propranolol had no effect on cue-induced reinstatement, indicative of no effect on

B -0 to-be-VEH

pranolol were not tested because nearly all previous studies that have demonstrated an effect of propranolol on the reconsolidation of appetitive as well as aversive behaviors have utilized a 10 $\mathrm{mg} / \mathrm{kg}$ dose (Przybyslawski et al. 1999; Debiec and LeDoux 2004; Bernardi et al. 2006; Diergaarde et al. 2006; Robinson and Franklin 2007; Milton et al. 2008; Robinson et al. 2011b; Achterberg et al. 2012; Wei and Li 2014; Schramm et al. 2015). Furthermore, a previous pilot study in our laboratory using a higher dose of propranolol $(40 \mathrm{mg} / \mathrm{kg})$ also revealed no propranolol-induced deficits in reinstatement or reconsolidation (data not shown), providing additional evidence that experiments using this higher dose may not be warranted.

\section{Discussion}

The results of the present study indicate that post-reactivation injection of cycloheximide dose-dependently $(2.2 \mathrm{mg} / \mathrm{kg}$ but not $1.0 \mathrm{mg} / \mathrm{kg}$ ) blocks cue-induced reinstatement. The effect of cycloheximide depends upon retrieval of the drug-related CS, indicating that cycloheximide interferes with memory reconsolidation. In contrast to the origi-
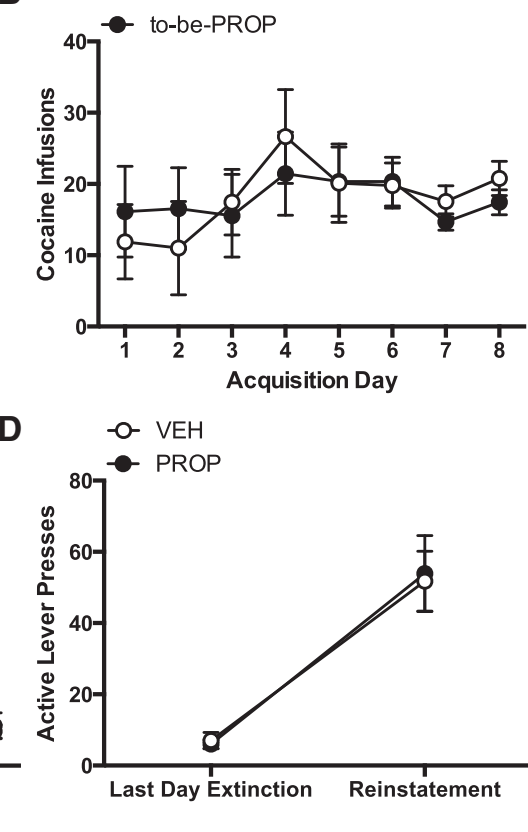

Figure 4. Propranolol $(10 \mathrm{mg} / \mathrm{kg})$ has no effect on reconsolidation or cue-induced reinstatement. $(A)$ Schematic representation of the experimental procedures. $(B)$ Total number of cocaine infusions received across each day of self-administration. (C) Total number of active lever presses during lever extinction. $(D)$ Active lever presses on the last day of extinction and on the cue-induced reinstatement test. 
reconsolidation. Thus, protein synthesis inhibition, but not $\beta$-adrenergic inhibition, blocks reconsolidation of a drug-related cue memory in a rodent model of cocaine self-administration.

It is not surprising, however, that propranolol failed to block reconsolidation as measured by cue-induced reinstatement. Previous research indicates that propranolol is not always effective at interfering with reconsolidation in both rodents (Lee and Everitt 2008; Font and Cunningham 2012; Milton et al. 2012; Williams and Harding 2014) and humans (Tollenaar et al. 2009; Bos et al. 2014; Pachas et al. 2015; Spring et al. 2015; Wood et al. 2015), and replications of experiments even within the same laboratory have produced differing results (Kindt et al. 2009; Bos et al. 2014). Some explanations for these inconsistencies include the ability of propranolol to preferentially affect emotional memories over neutral memories (Schwabe et al. 2012a,b), individual differences in participants (Soeter and Kindt 2013), and the mnemonic paradigm under investigation (Muravieva and Alberini 2010; Wei and Li 2014). Furthermore, prior experience with drugs of abuse may engender memories resistant to propranolol blockade (Robinson et al. 2011a; Ortiz et al. 2015), which could explain the present results.

It cannot be ruled out that alterations to the design of the present paradigm might reveal an effect of propranolol on reconsolidation of a cocaine-cue memory. For example, some prior studies have found that repeated reactivation sessions followed by propranolol are required to block reconsolidation (Fricks-Gleason and Marshall 2008; Wouda et al. 2010), yet the present study utilized only a single reactivation session. In addition, it is possible that administering propranolol prior to memory reactivation may induce deficits in reinstatement. However, only drugs administered after memory reactivation can be said to interfere with the restabilization phase of reconsolidation (Milton et al. 2013). Compounds administered prior to reactivation, conversely, may interfere with memory due to an enhancement of memory destabilization or through interfering directly with memory recall (Ben Mamou et al. 2006; Hong et al. 2011). The ability of propranolol to reduce cue-induced reinstatement through either of these alternative processes may be an interesting avenue for future investigation.

Additionally, while it is possible that propranolol may decrease reinstatement at a different dose, nearly all studies demonstrating propranolol's ability to block reconsolidation systemically have used the same dose $(10 \mathrm{mg} / \mathrm{kg})$ as was used here in both aversive (Przybyslawski et al. 1999; Debiec and LeDoux 2004) and appetitive paradigms (Bernardi et al. 2006; Diergaarde et al. 2006; Robinson and Franklin 2007; Milton et al. 2008; Robinson et al. 2011b; Achterberg et al. 2012; Wei and Li 2014; Schramm et al. 2015). Reports of lower effective doses ( 1 or $5 \mathrm{mg} / \mathrm{kg}$ ) of propranolol have only been shown to block reconsolidation of drug CPP in stress-exposed mice (Hymel et al. 2014) or of contextual fear memories after very high shock-conditioning sessions in rats (Abrari et al. 2008). Higher doses have not generally been used in reconsolidation studies; however, a $40 \mathrm{mg} / \mathrm{kg}$ dose of propranolol given subcutaneously was reported to reduce morphine CPP (Robinson et al. 2011b). The use of a higher dose was not required, as a $10 \mathrm{mg} / \mathrm{kg}$ dose also impaired morphine CPP in the same study. Additionally, when we ran a pilot study using this high dose $(40 \mathrm{mg} / \mathrm{kg})$, we found no propranolol-induced deficits in reinstatement or reconsolidation (AB Dunbar and JR Taylor, unpubl.). Use of systemic propranolol at these higher doses is also problematic in terms of possible nonspecific mnemonic or molecular consequences. Thus, it is unlikely that the null effect of propranolol seen here is due to dosage, though this hypothesis would need to be experimentally evaluated.

The instrumental behavior of cue-induced reinstatement is modulated by three main Pavlovian processes: conditioned rein- forcement, conditioned approach, and conditioned motivation (Milton and Everitt 2010). While post-reactivation propranolol has been shown to reduce conditioned reinforcement in a rodent model of cocaine self-administration (Milton et al. 2008), preliminary data from the same laboratory indicate that under the same conditions post-reactivation propranolol may not block cue-induced reinstatement (Milton and Everitt 2009, 2010), which is supported by the present results. Furthermore, while alcohol conditioned reinforcement is blocked by post-reactivation propranolol similarly to cocaine (Milton et al. 2008; Schramm et al. 2015), alcohol conditioned motivation and approach are not (Lee and Everitt 2008; Milton et al. 2012), and the effect of propranolol on cue-induced reinstatement to alcohol-seeking is unclear (Wouda et al. 2010; Williams and Harding 2014). Thus, it is likely that propranolol selectively or preferentially modifies the reconsolidation of conditioned reinforcement. Blocking a conditioned reinforcement memory may not be sufficient to decrease cue-induced reinstatement if conditioned motivation and approach memories are intact. Conversely, protein synthesis inhibitors administered intracranially (anisomycin; Barak et al. 2013; Sorg et al. 2015) and systemically (cycloheximide; present results) do block reinstatement to drug seeking, and intraamygdalar protein synthesis inhibition (anisomycin) also blocks conditioned reinforcement (Lee et al. 2005). The role of protein synthesis inhibition in conditioned motivation and approach has yet to be examined. Protein synthesis inhibition may, thus, modulate the memories of different or additional drug-related psychological processes when compared with propranolol, which enables cycloheximide and anisomycin to block reinstatement to drug seeking. Additional research is needed to directly test the ability of propranolol and cycloheximide to interfere with the reconsolidation of different aspects of cocaine-related memories.

The present finding that post-reactivation cycloheximide attenuates cue-induced reinstatement to cocaine seeking is a valuable contribution to the field as it demonstrates that systemic protein synthesis inhibition blocks reconsolidation. The only systemic agents that have previously been found to block reconsolidation as measured by decreased reinstatement are dopamine and NMDAR antagonists (Yan et al. 2014; Exton-McGuinness and Lee 2015). Understanding how reconsolidation can be blocked systemically is essential for improving the translational potential of reconsolidation-based relapse-prevention therapies. Although cycloheximide is not itself suitable for use in humans, future research should investigate the efficacy of other protein synthesis inhibitors with reduced human toxicity, such antibiotics that target protein synthesis (McCoy et al. 2011; Sutcliffe 2011), at blocking reconsolidation of drug-related memories. The role of protein synthesis inhibition on blocking memory reconsolidation as measured by reduced reinstatement to drug-seeking behavior deserves further investigation as a potential treatment for addiction.

\section{Materials and Methods}

\section{Subjects}

One hundred male Sprague Dawley rats (250-275 g; Charles River Laboratories) were individually housed on a 12-h light cycle in a temperature and humidity controlled room. All procedures were conducted during the light phase of the cycle. Rats were allowed to acclimate for $7 \mathrm{~d}$ prior to the start of the experiment. All procedures were conducted in accordance with the policies of the Yale University Institutional Animal Care and Use Committee and conformed to National Institutes of Health Guidelines on the Care and Use of Laboratory Animals. 


\section{Surgery}

Animals were anesthetized with ketamine $(100 \mathrm{mg} / \mathrm{kg}$, i.p.) and xylazine $(5 \mathrm{mg} / \mathrm{kg}$, i.p.) and injected with carprofen $(5 \mathrm{mg} / \mathrm{kg}$, s.c.) and saline (5 mL, s.c.). Rats were implanted with a chronic, indwelling catheter $(0.51 \times 0.94 \mathrm{~mm}$, Dow Corning $)$ in the right jugular vein. The catheter tubing connected to a cannula (22 gauge, Plastics One) mounted on the back of the animals. The intravenous catheter was flushed with $0.4 \mathrm{mg}$ gentamicin $(0.2 \mathrm{~mL}$, Sagent) at surgery and patency was maintained post-surgery by infusion of $0.2 \mathrm{~mL}$ of saline containing heparin (35 U/mL, Sagent) and gentamicin $(0.08 \mathrm{mg} / \mathrm{mL}$, Hospira) every $2 \mathrm{~d}$. Patency was verified by the infusion of $2 \mathrm{mg}$ of methoxhexital sodium $(0.2 \mathrm{~mL}$, Par). Animals were allowed to recover for $5-7 \mathrm{~d}$ before the start of behavioral procedures.

\section{Behavioral apparatus}

Behavioral procedures took place in sound-attenuating operant chambers (Med Associates). Context A contained a metal rod floor, two inactive nose ports, an inactive magazine, two retractable levers positioned on the same side of the box, two cue lights positioned directly above the levers, and a fan that provided background noise (65 dB). A metal arm (Med Associates) attached to the operant box held up a spring tether that attached to the back mount on the rats for intravenous cocaine delivery through the catheter. A syringe pump placed outside of the sound-attenuating chamber was connected to the other end of the spring tether by polyethylene tubing (Plastics One) to deliver cocaine infusions. Context B contained an opaque white plastic floor, an illuminated house light, and no fan, levers, nose ports, or magazine. Context B was additionally scented with $1 \%$ almond extract.

\section{Behavioral procedures}

Rats were restricted to $90 \%$ of their free-feeding weight and fed daily to maintain that weight throughout the experiment. Behavioral procedures are similar to those used in previous studies (Sanchez et al. 2010; Wan et al. 2014). Animals underwent acquisition of cocaine self-administration in Context A for $8 \mathrm{~d}$ (propranolol experiment) or $10 \mathrm{~d}$ (cycloheximide experiments) in daily 1 -h sessions. Rats were placed in the operant chamber and secured to the spring tether. Each active lever press resulted in one infusion of cocaine $(0.5 \mathrm{mg} / \mathrm{kg})$, followed by a 10 -sec timeout. Each cocaine infusion was paired with a CS a 10-sec illumination of the cue light and a simultaneous 10 -sec tone (75-80 dB). Inactive lever presses were recorded but had no outcome. Rats were removed from the chambers and returned to their home cage after $60 \mathrm{~min}$. Catheter patency was verified after the last day of self-administration by the infusion of $2 \mathrm{mg}$ of methohexital sodium $(0.2 \mathrm{~mL}$, Par). Rats next underwent $8 \mathrm{~d}$ of lever extinction training in Context A, in which they were placed in the operant chambers for $1 \mathrm{~h}$ per day. No CS presentations or cocaine infusions were available during extinction.

In groups that underwent memory reactivation, the CSmemory retrieval session occurred $24 \mathrm{~h}$ following the last day of extinction. Rats were placed in Context B for 6-min total. After a 2-min acclimatization period, the CS was presented three times (1-min intertrial interval), and rats remained in the box for an additional $2 \mathrm{~min}$. In control groups without memory reactivation, rats did not undergo memory retrieval but instead were placed in Context B for $6 \mathrm{~min}$ without any CS presentations. Immediately upon removal from the boxes, rats were injected with cycloheximide (s.c., 1.0 or $2.2 \mathrm{mg} / \mathrm{kg}$ in 15\% DMSO, Sigma), propranolol (i.p., $10 \mathrm{mg} / \mathrm{kg}$ in saline, Sigma) or vehicle and returned to their home cages. The drug doses chosen have previously been demonstrated to block reconsolidation in other paradigms for both doses of cycloheximide (Flint et al. 2007; Taubenfeld et al. 2010) and for propranolol (Debiec and LeDoux 2004; Milton et al. 2008).

Seventy-two hours (cycloheximide experiments) or $24 \mathrm{~h}$ (propranolol experiment) later, animals were tested on cueinduced reinstatement. Rats were placed in Context A for $1 \mathrm{~h}$. One presentation of the CS was given freely 5 sec after the session began. For the duration of the session, each active lever press resulted in the contingent presentation of the CS. No cocaine infusions were presented during reinstatement. Inactive lever presses were recorded but had no associated outcome. Rats were removed from the boxes and returned to their home cages.

\section{Statistical analysis}

Rats that did not acquire self-administration $(<50$ total cocaine infusions or $<10$ infusions on the final day of self-administration) or whose catheters were not patent at the end of selfadministration training were excluded from all statistical analyses. All analyses were carried out using SPSS version 23. Acquisition of self-administration was analyzed with repeatedmeasures analyses of variance (rm-ANOVAs) across the 8 or $10 \mathrm{~d}$ of self-administration on number of cocaine infusions, number of active lever presses and number of inactive lever presses. Lever extinction was analyzed with rm-ANOVAs across $8 \mathrm{~d}$ on number of active and inactive lever presses. To analyze reinstatement results, rm-ANOVAs across session (last day of extinction versus reinstatement test) were conducted on number of active and inactive lever presses. Following significant rm-ANOVAs, planned comparisons (one-way ANOVAs) were performed on active lever presses between groups during extinction and reinstatement.

\section{Acknowledgments}

This work was supported by DA015222 (J.R.T.), the Charles B.G. Murphy Fund, the Connecticut Department of Mental Health and Addiction Services, and the NSF Graduate Research Fellowship Program. We thank Hayde Sanchez for assistance and Drs Stephanie M. Groman, Melissa S. Monsey, Mary M. Torregrossa, and Stacey L. Quick for helpful discussions.

\section{References}

Abrari K, Rashidy-Pour A, Semnanian S, Fathollahi Y. 2008. Administration of corticosterone after memory reactivation disrupts subsequent retrieval of a contextual conditioned fear memory: dependence upon training intensity. Neurobiol Learn Mem 89: 178-184.

Achterberg EJ, Trezza V, Vanderschuren LJ. 2012. $\beta$-adrenoreceptor stimulation mediates reconsolidation of social reward-related memories. PLoS One 7: e39639.

Balderas I, Rodriguez-Ortiz CJ, Bermudez-Rattoni F. 2015. Consolidation and reconsolidation of object recognition memory. Behav Brain Res 285: $213-222$.

Barak S, Liu F, Ben Hamida S, Yowell QV, Neasta J, Kharazia V, Janak PH, Ron D. 2013. Disruption of alcohol-related memories by mTORC1 inhibition prevents relapse. Nat Neurosci 16: 1111-1117.

Ben Mamou C, Gamache K, Nader K. 2006. NMDA receptors are critical for unleashing consolidated auditory fear memories. Nat Neurosci 9: 1237-1239.

Bernardi RE, Lattal KM, Berger SP. 2006. Postretrieval propranolol disrupts a cocaine conditioned place preference. Neuroreport 17: 1443-1447.

Bos MG, Beckers T, Kindt M. 2014. Noradrenergic blockade of memory reconsolidation: a failure to reduce conditioned fear responding. Front Behav Neurosci 8: 412 .

Bouton ME. 2004. Context and behavioral processes in extinction. Learn Mem 11: 485-494.

Contreras M, Billeke P, Vicencio S, Madrid C, Perdomo G, González M, Torrealba F. 2012. A role for the insular cortex in long-term memory for context-evoked drug craving in rats. Neuropsychopharmacology 37: 2101-2108.

Debiec J, LeDoux JE. 2004. Disruption of reconsolidation but not consolidation of auditory fear conditioning by noradrenergic blockade in the amygdala. Neuroscience 129: 267-272.

Diergaarde L, Schoffelmeer AN, De Vries TJ. 2006. $\beta$-Adrenoceptor mediated inhibition of long-term reward-related memory reconsolidation. Behav Brain Res 170: $333-336$.

Exton-McGuinness MT, Lee JL. 2015. Reduction in responding for sucrose and cocaine reinforcement by disruption of memory reconsolidation. eNeuro 2. doi: 10.1523/ENEURO.0009-15.2015.

Fan HY, Cherng CG, Yang FY, Cheng LY, Tsai CJ, Lin LC, Yu L. 2010. Systemic treatment with protein synthesis inhibitors attenuates the expression of cocaine memory. Behav Brain Res 208: 522-527. 
Fang Q, Li FQ, Li YQ, Xue YX, He YY, Liu JF, Lu L, Wang JS. 2011. Cannabinoid CB1 receptor antagonist rimonabant disrupts nicotine reward-associated memory in rats. Pharmacol Biochem Behav 99: $738-742$.

Flint RW Jr, Valentine S, Papandrea D Jr. 2007. Reconsolidation of a long-term spatial memory is impaired by cycloheximide when reactivated with a contextual latent learning trial in male and female rats. Neuroscience 148: 833-844.

Font L, Cunningham CL. 2012. Post-retrieval propranolol treatment does not modulate reconsolidation or extinction of ethanol-induced conditioned place preference. Pharmacol Biochem Behav 101: 222-230.

Fricks-Gleason AN, Marshall JF. 2008. Post-retrieval $\beta$-adrenergic receptor blockade: effects on extinction and reconsolidation of cocaine-cue memories. Learn Mem 15: 643-648.

Hellemans KG, Everitt BJ, Lee JLC. 2006. Disrupting reconsolidation of conditioned withdrawal memories in the basolateral amygdala reduces suppression of heroin seeking in rats. J Neurosci 26: 12694-12699.

Hong I, Kim J, Song B, Park S, Lee J, Kim J, An B, Lee S, Choi S. 2011. Modulation of fear memory by retrieval and extinction: a clue for memory deconsolidation. Rev Neurosci 22: 205-229.

Hymel KA, Eans SO, L Sitchenko K, Gomes SM, Lukowsky AL, Medina JM Sypek EI, Carey AN, McLaughlin JP. 2014. Stress-induced increases in depression-like and cocaine place-conditioned behaviors are reversed by disruption of memories during reconsolidation. Behav Pharmacol 25: 599-608.

Jian M, Luo YX, Xue YX, Han Y, Shi HS, Liu JF, Yan W, Wu P, Meng SQ, Deng JH, et al. 2014. eIF2 $\alpha$ dephosphorylation in basolateral amygdala mediates reconsolidation of drug memory. J Neurosci 34: 10010-10021.

Jones B, Bukoski E, Nadel L, Fellous JM. 2012. Remaking memories: reconsolidation updates positively motivated spatial memory in rats. Learn Mem 19: 91-98.

Kindt M, Soeter M, Vervliet B. 2009. Beyond extinction: erasing human fear responses and preventing the return of fear. Nat Neurosci 12: 256-258.

Lee JL, Everitt BJ. 2008. Reactivation-dependent amnesia in Pavlovian approach and instrumental transfer. Learn Mem 15: 597-602.

Lee JL, Di Ciano P, Thomas KL, Everitt BJ. 2005. Disrupting reconsolidation of drug memories reduces cocaine-seeking behavior. Neuron 47: 795-801.

Lee JL, Milton AL, Everitt BJ. 2006. Reconsolidation and extinction of conditioned fear: inhibition and potentiation. J Neurosci 26: $10051-10056$

McCoy LS, Xie Y, Tor Y. 2011. Antibiotics that target protein synthesis. Wiley Interdiscip Rev RNA 2: 209-232.

Milekic MH, Brown SD, Castellini C, Alberini CM. 2006. Persistent disruption of an established morphine conditioned place preference. J Neurosci 26: 3010-3020.

Milton AL, Everitt BJ. 2009. NMDA receptors and $\beta$-adrenergic receptors as molecular targets for the prevention of relapse to drug-seeking. Eur Neuropsychopharmacol 19: S86-S87.

Milton AL, Everitt BJ. 2010. The psychological and neurochemical mechanisms of drug memory reconsolidation: implications for the treatment of addiction. Eur J Neurosci 31: 2308-2319.

Milton AL, Lee JL, Everitt BJ. 2008. Reconsolidation of appetitive memories for both natural and drug reinforcement is dependent on $\{\beta\}$-adrenergic receptors. Learn Mem 15: 88-92.

Milton AL, Schramm MJ, Wawrzynski JR, Gore F, Oikonomou-Mpegeti F, Wang NQ Samuel D, Economidou D, Everitt BJ. 2012. Antagonism at NMDA receptors, but not $\beta$-adrenergic receptors, disrupts the reconsolidation of pavlovian conditioned approach and instrumental transfer for ethanol-associated conditioned stimuli. Psychopharmacology (Berl) 219: 751-761.

Milton AL, Merlo E, Ratano P, Gregory BL, Dumbreck JK, Everitt BJ. 2013 Double dissociation of the requirement for GluN2B- and GluN2A-containing NMDA receptors in the destabilization and restabilization of a reconsolidating memory. J Neurosci 33: 1109-1115.

Morris RG, Inglis J, Ainge JA, Olverman HJ, Tulloch J, Dudai Y, Kelly PA. 2006. Memory reconsolidation: sensitivity of spatial memory to inhibition of protein synthesis in dorsal hippocampus during encoding and retrieval. Neuron 50: 479-489.

Muravieva EV, Alberini CM. 2010. Limited efficacy of propranolol on the reconsolidation of fear memories. Learn Mem 17: 306-313.

Nader K, Schafe GE, Le Doux JE. 2000a. Fear memories require protein synthesis in the amygdala for reconsolidation after retrieval. Nature 406: $722-726$.

Nader K, Schafe GE, LeDoux JE. 2000b. The labile nature of consolidation theory. Nat Rev Neurosci 1: 216-219.

Ortiz V, Giachero M, Espejo PJ, Molina VA, Martijena ID. 2015. The effect of Midazolam and Propranolol on fear memory reconsolidation in ethanol-withdrawn rats: influence of d-cycloserine. Int J Neuropsychopharmacol 18. doi: 10.1093/ijnp/pyu082.
Otis JM, Dashew KB, Mueller D. 2013. Neurobiological dissociation of retrieval and reconsolidation of cocaine-associated memory. J Neurosci 33: $1271-1281$.

Pachas GN, Gilman J, Orr SP, Hoeppner B, Carlini SV, Grasser EB, Loebl T, Nino J, Pitman RK, Evins AE. 2015. Single dose propranolol does not affect physiologic or emotional reactivity to smoking cues. Psychopharmacology (Berl) 232: 1619-1628.

Prus AJ, James JR, Rosecrans JA. 2009. Conditioned place preference. In Methods of behavior analysis in neuroscience. Frontiers in neuroscience (ed. Buccafusco JJ), pp. 59-77. CRC Press/Taylor \& Francis, Boca Raton, FL. http://www.ncbi.nlm.nih.gov/books/NBK5229/ (Accessed December 21, 2015).

Przybyslawski J, Roullet P, Sara SJ. 1999. Attenuation of emotional and nonemotional memories after their reactivation: role of $\beta$ adrenergic receptors. J Neurosci 19: 6623-6628.

Robinson MJ, Franklin KB. 2007. Central but not peripheral $\beta$-adrenergic antagonism blocks reconsolidation for a morphine place preference. Behav Brain Res 182: 129-134.

Robinson MJ, Franklin KB. 2010. Reconsolidation of a morphine place preference: impact of the strength and age of memory on disruption by propranolol and midazolam. Behav Brain Res 213: 201-207.

Robinson MJ, Armson M, Franklin KB. 2011a. The effect of propranolol and midazolam on the reconsolidation of a morphine place preference in chronically treated rats. Front Behav Neurosci 5: 42.

Robinson MJ, Ross EC, Franklin KB. 2011b. The effect of propranolol dose and novelty of the reactivation procedure on the reconsolidation of a morphine place preference. Behav Brain Res 216: 281-284.

Rodriguez-Ortiz CJ, Bermudez-Rattoni F. 2007. Memory reconsolidation or updating consolidation? In Neural plasticity and memory: from genes to brain imaging (ed. Bermudez-Rattoni F), CRC Press, Boca Raton, FL. http:// europepmc.org/abstract/med/21204424 (Accessed December 22, 2015).

Sadler R, Herzig V, Schmidt WJ. 2007. Repeated treatment with the NMDA antagonist MK-801 disrupts reconsolidation of memory for amphetamine-conditioned place preference. Behav Pharmacol 18: 699-703.

Saladin ME, Gray KM, McRae-Clark AL, Larowe SD, Yeatts SD, Baker NL, Hartwell KJ, Brady KT. 2013. A double blind, placebo-controlled study of the effects of post-retrieval propranolol on reconsolidation of memory for craving and cue reactivity in cocaine dependent humans. Psychopharmacology (Berl) 226: 721-737.

Sanchez H, Quinn JJ, Torregrossa MM, Taylor JR. 2010. Reconsolidation of a cocaine-associated stimulus requires amygdalar protein kinase A. J Neurosci 30: 4401-4407.

Schramm MJ, Everitt BJ, Milton AL. 2015. Bidirectional modulation of alcohol-associated memory reconsolidation through manipulation of adrenergic signaling. Neuropsychopharmacology 41: 1103-1111.

Schwabe L, Nader K, Pruessner JC. 2012a. $\beta$-Adrenergic blockade during reactivation reduces the subjective feeling of remembering associated with emotional episodic memories. Biol Psychol 92: 227-232.

Schwabe L, Nader K, Wolf OT, Beaudry T, Pruessner JC. 2012b. Neural signature of reconsolidation impairments by propranolol in humans. Biol Psychiatry 71: 380-386.

Soeter M, Kindt M. 2013. High trait anxiety: a challenge for disrupting fear memory reconsolidation. PLoS One 8: e75239.

Sorg BA. 2012. Reconsolidation of drug memories. Neurosci Biobehav Rev 36: $1400-1417$

Sorg BA, Todd RP, Slaker M, Churchill L. 2015. Anisomycin in the medial prefrontal cortex reduces reconsolidation of cocaine-associated memories in the rat self-administration model. Neuropharmacology 92: $25-33$.

Spring JD, Wood NE, Mueller-Pfeiffer C, Milad MR, Pitman RK, Orr SP. 2015. Prereactivation propranolol fails to reduce skin conductance reactivity to prepared fear-conditioned stimuli. Psychophysiology 52: 407-415.

Sutcliffe JA. 2011. Antibiotics in development targeting protein synthesis. Ann N Y Acad Sci 1241: 122-152.

Taubenfeld SM, Muravieva EV, Garcia-Osta A, Alberini CM. 2010. Disrupting the memory of places induced by drugs of abuse weakens motivational withdrawal in a context-dependent manner. Proc Natl Acad Sci 107: 12345-12350.

Taylor JR, Torregrossa MM. 2015. Pharmacological disruption of maladaptive memory. Handb Exp Pharmacol 228: 381-415.

Taylor JR, Olausson P, Quinn JJ, Torregrossa MM. 2009. Targeting extinction and reconsolidation mechanisms to combat the impact of drug cues on addiction. Neuropharmacology 56(Suppl 1): 186-195.

Tedesco V, Mutti A, Auber A, Chiamulera C. 2014. Nicotine-seeking reinstatement is reduced by inhibition of instrumental memory reconsolidation. Behav Pharmacol 25: 725-731.

Tollenaar MS, Elzinga BM, Spinhoven P, Everaerd W. 2009. Immediate and prolonged effects of cortisol, but not propranolol, on memory retrieval in healthy young men. Neurobiol Learn Mem 91: 23-31. 
Torregrossa MM, Taylor JR. 2013. Learning to forget: manipulating extinction and reconsolidation processes to treat addiction. Psychopharmacology (Berl) 226: 659-672.

Torregrossa MM, Taylor JR. 2016. Neuroscience of learning and memory for addiction medicine: from habit formation to memory reconsolidation. Prog Brain Res 223: 91-113.

Tronson NC, Taylor JR. 2007. Molecular mechanisms of memory reconsolidation. Nat Rev Neurosci 8: 262-275.

Tronson NC, Wiseman SL, Olausson P, Taylor JR. 2006. Bidirectional behavioral plasticity of memory reconsolidation depends on amygdalar protein kinase A. Nat Neurosci 9: 167-169.

Valjent E, Corbillé AG, Bertran-Gonzalez J, Hervé D, Girault JA. 2006. Inhibition of ERK pathway or protein synthesis during reexposure to drugs of abuse erases previously learned place preference. Proc Natl Acad Sci 103: 2932-2937.

Wan X, Torregrossa MM, Sanchez H, Nairn AC, Taylor JR. 2014. Activation of exchange protein activated by cAMP in the rat basolateral amygdala impairs reconsolidation of a memory associated with self-administered cocaine. PLoS One 9: e107359.

Wei S, Li X. 2014. Differential effects of propranolol on conditioned hyperactivity and locomotor sensitization induced by morphine in rats. Sci Rep 4: 3786 .

Williams KL, Harding KM. 2014. Repeated alcohol extinction sessions in conjunction with MK-801, but not yohimbine or propranolol, reduces subsequent alcohol cue-induced responding in rats. Pharmacol Biochem Behav 116: $16-24$

Winters BD, Tucci MC, DaCosta-Furtado M. 2009. Older and stronger object memories are selectively destabilized by reactivation in the presence of new information. Learn Mem 16: 545-553.
Wood NE, Rosasco ML, Suris AM, Spring JD, Marin MF, Lasko NB, Goetz JM, Fischer AM, Orr SP, Pitman RK. 2015. Pharmacological blockade of memory reconsolidation in posttraumatic stress disorder: three negative psychophysiological studies. Psychiatry Res 225: $31-39$.

Wouda JA, Diergaarde L, Riga D, van Mourik Y, Schoffelmeer AN, De Vries TJ. 2010. Disruption of long-term alcohol-related memory reconsolidation: role of $\beta$-adrenoceptors and NMDA receptors. Front Behav Neurosci 4: 179.

Yan Y, Newman AH, Xu M. 2014. Dopamine D1 and D3 receptors mediate reconsolidation of cocaine memories in mouse models of drug self-administration. Neuroscience 278: 154-164.

Yu YJ, Chang CH, Gean PW. 2013. AMPA receptor endocytosis in the amygdala is involved in the disrupted reconsolidation of Methamphetamine-associated contextual memory. Neurobiol Learn Mem 103: 72-81.

Zhao LY, Sun LL, Shi J, Li P, Zhang Y, Lu L. 2011a. Effects of $\beta$-adrenergic receptor blockade on drug-related memory reconsolidation in abstinent heroin addicts. Drug Alcohol Depend 118: $224-229$.

Zhao X, Li Y, Peng T, Seese RR, Wang Z. 2011b. Stress impairs consolidation of recognition memory after blocking drug memory reconsolidation. Neurosci Lett 501: 50-54.

Received May 3, 2016; accepted in revised form May 18, 2016. 


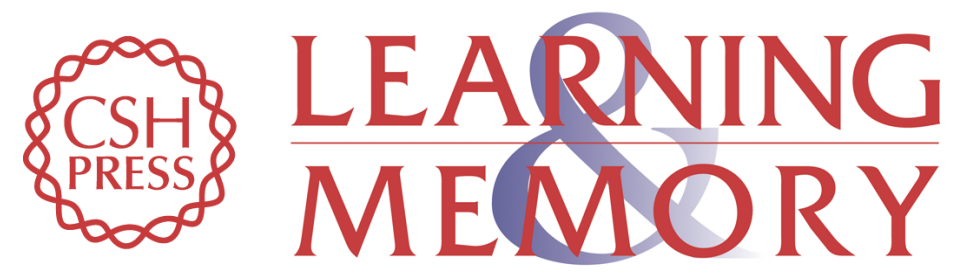

\section{Inhibition of protein synthesis but not $\beta$-adrenergic receptors blocks reconsolidation of a cocaine-associated cue memory}

Amber B. Dunbar and Jane R. Taylor

Learn. Mem. 2016, 23:

Access the most recent version at doi:10.1101/Im.042838.116

\begin{aligned} & \hline References $\begin{array}{l}\text { This article cites } 76 \text { articles, } 18 \text { of which can be accessed free at: } \\ \text { http://learnmem.cshlp.org/content/23/8/391.full.html\#ref-list-1 }\end{array} \\ & \begin{array}{r}\text { Creative } \\ \text { Commons } \\ \text { License }\end{array} \begin{array}{l}\text { This article is distributed exclusively by Cold Spring Harbor Laboratory Press for the } \\ \text { first } 12 \text { months after the full-issue publication date (see } \\ \text { http://learnmem.cshlp.org/site/misc/terms.xhtml). After } 12 \text { months, it is available under } \\ \text { a Creative Commons License (Attribution-NonCommercial } 4.0 \text { International), as } \\ \text { described at http://creativecommons.org/licenses/by-nc/4.0/. }\end{array} \\ & \begin{array}{c}\text { Receive free email alerts when new articles cite this article - sign up in the box at the } \\ \text { top right corner of the article or click here. }\end{array} \\ & \begin{array}{l}\text { Service } \\ \text { terting }\end{array}\end{aligned}$ 